\title{
Characteristics of falls in elderly persons residing in the community: a population-based study
}

\section{Suzana Albuquerque de Moraes Wuber Jefferson Sousa Soares ${ }^{1}$ Lygia Paccini Lustosa² Tereza Loffredo Bilton ${ }^{3}$ Eduardo Ferriolit Monica Rodrigues Perracini'}

\section{Abstract}

Object: to examine the characteristics to the last fall of Brazilian elderly persons who experienced falls in 2008 and 2009, and to identify if there is a relationship with sociodemographic characteristics, physical health, comorbidities, clinical conditions and the circumstances of the falls. Methods: a cross-sectional, population based study was carried out with participants aged 65 and older from Barueri in the state of São Paulo and Cuiabá in the state of Mato Grosso, Brazil. Households were enrolled within each census region according to population density and the number of elderly persons living in each region. A multidimensional questionnaire composed of sociodemographic factors and data regarding falls was used. Associations were analyzed using contingency tables, and Fisher's Exact or Pearson's Chi-square test was used. Results: 774 elderly people were included in the study, 299 of whom reported falling in the previous year. Of these, 176 $(58.9 \%)$ had fallen once and $123(41.1 \%)$ reported having fallen twice or more. Among fallers the mean age was $72.53( \pm 6.12)$ years and $214(71.6 \%)$ were female. About 107 $(35.8 \%)$ of the elderly reported having fallen forwards, $79(26.4 \%)$ fell to the side and $42(14 \%)$ fell backwards. Regarding the circumstances of the falls, 107 (35.8\%) reported having lost their balance, 79 (26.4\%) said they had stumbled and $42(14 \%)$ said they had slipped. There was an association between the mechanism and circumstances of the falls and having fallen once or twice or more. There was an association between the circumstances of falls and the number of medications taken. Conclusion: The characteristics of falls were different among elderly persons who had fallen once or twice or more, which may guide health professionals, the elderly and their families in relation to specific fall prevention strategies.

\footnotetext{
Universidade Cidade de São Paulo, Programa de Mestrado e Doutorado em Fisioterapia. São Paulo, SP, Brasil.

2 Universidade Federal de Minas Gerais, Departamento de Fisioterapia. Belo Horizonte, MG, Brasil.

Pontifícia Universidade Católica de São Paulo, Departamento de Fonoaudiologia. São Paulo, SP, Brasil.

4 Universidade de São Paulo, Faculdade de Medicina. Ribeirão Preto, SP, Brasil.
}

Research funding: Conselho Nacional de Desenvolvimento Científico e Tecnológico (National Council for Scientific and Technological Development) (CNPq). Process number: 555087 / 2006-9. Fundação de Amparo à Pesquisa do Estado de Mato Grosso (Mato Grosso Research Support Foundation) (FAPEMAT). Process number: 555078 / 2006-0.
Keyword: Elderly. Accidental Falls. Epidemiology. 


\section{INTRODUCTION}

Increased longevity and life expectancy have brought changes in the epidemiological profile of the population, with an increase in the prevalence of non-transmissible chronic degenerative diseases, falls, and functional disability, such as reduced muscle strength and body balance ${ }^{1}$. These changes have an impact on the health system, both in terms of costs and the need to develop health care strategies at all levels².

The incidence and the severity of falls increase considerably after the sixth decade of life, tripling the rates of hospitalization among the elderly after the age of $65^{3}$. It is estimated that $30 \%$ of 60 -year-olds living in the community fall every year, of whom half fall on a recurring basis. This proportion increases to $42 \%$ in elderly persons aged 70 years ${ }^{4}$. The prevalence of falls in Brazil varies from 30\% to 38.7\% $\%^{5}$. Falls are considered a major cause of injury and death among the elderly and represent a major public health concern ${ }^{4}$. They can lead to severe trauma in the elderly, such as hip fractures and head trauma, contributing to the decline of functional capacity and autonomy, institutionalization, and increased mortality $^{6}$. In Brazil, the Unified Health System spends more than $\mathrm{R} \$ 51$ million each year on the treatment of fractures caused by falls?

Falls are multifactorial events and stem from intrinsic and extrinsic factors. The first refer to the physiological alterations resulting from aging and sensory, neuromuscular, psycho-cognitive dysfunctions related to diseases and clinical conditions, compromising balance and gait ${ }^{8}$. Extrinsic factors include environmental hazards such as poor lighting, slippery or uneven flooring, loose rugs, high or narrow steps ${ }^{8}$ which are factors related to the circumstances of the fall. Some studies in literature indicate that $75 \%$ of the elderly suffer a fall in their own home compared to the elderly who fall outside the home? ${ }^{9}$ The room where most falls occur is the bedroom (25.2\%), followed by the kitchen $(16.8 \%)$ and the bathroom $(14.5 \%)^{10}$. This can be explained by the fact that older people spend much of their time in their homes because it is the safest and most familiar place for them. Possibly, at home the elderly reduce the attention they devote to locomotion due to greater self-confidence and familiarity when moving between rooms ${ }^{11}$.

Considering the serious harm that falls can cause in the elderly population, identifying the characteristics of the most recent fall through a population-based study allows populations to be characterized and preventive measures to be designed that avoid the occurrence of further falls. The analysis of the history of a fall event is established by the guidelines of the American Geriatrics Society and the British Geriatrics Society (Clinical Practice Guideline for Prevention of Falls in Older Persons) ${ }^{12}$. The characteristics of falls, particularly mechanisms and circumstances, can help identify profiles of elderly fallers and trigger assessment and intervention strategies.

The objective of the present study was to explore the characteristics of the most recent falls of Brazilian elderly persons who had fallen in the last year (2008 and 2009) and to identify if there is a relationship with sociodemographic characteristics, physical health, comorbidities, clinical conditions and the circumstances of the falls

\section{METHOD}

This is a cross-sectional population-based study, with a sample of 774 community-dwelling elderly people living in the city of Barueri, São Paulo and Cuiabá, Mato Grosso, Brazil. The study is part of a multi-center research project, made up of a multidisciplinary research network, called the FIBRA Network (Rede de Estudo da Fragilidade em Idosos Brasileiros) (Study Network of Frailty in Brazilian Elderly People).

The sample of the present study was composed of elderly individuals aged 65 years or older, male and female, living in the community in the municipality of Barueri and Cuiabá, Brazil, from March 2009 to April 2010. The sample was collected according to the causal clustering by area sampling method. In order to calculate the sample of each city, the sample size required based on a population proportion of $50 \%$ of a given characteristic under study (the value in which the sample size obtained is the maximum possible ( $p=0.50, \mathrm{q}=0.50$ ), according to the elderly 
population of each city). The level of significance was set at 5\% (alpha $=5 \%, Z=1.96$ ). Based on these calculations, the sample size for locations with less than one million inhabitants was 385 elderly persons. For the number and location of the households to be visited, IBGE data were used to locate the elderly. The proportion of elderly people in each census area was calculated in relation to the total number of elderly people in each city. Then, in each census sector, the density of elderly persons per household was calculated. After that, the number of elderly people in each census tract was divided by the density of the elderly per household, to obtain the number of households to be visited. Maps were provided by the IBGE and the city councils were provided to draw the blocks, and those where homes were to be visited were identified, counted and drawn. In each census area, an additional and proportional number of blocks was selected to cover refusals and absences (10\%) and to compensate for losses due to the exclusion criteria $(20 \%)$.

The categorical refusal of the elderly persons to participate, their declaration of impossibility or intention to interrupt their participation was considered as refusal. The elderly were approached up to three times before being considered a "refusal". Absences were considered where there was no answer at a house on the days of the first and two further visits. Participants with the following characteristics were excluded: a) severe cognitive deficit suggestive of dementia, evaluated by the mini mental state examination, adjusted for schooling, minus one standard deviation ${ }^{13}$, b) wheelchair-bound or restricted to bed, provisionally or definitively; c) severe stroke sequelae, with localized loss of strength; d) severe or unstable Parkinson's disease; e) terminal stage cancer and those in treatment for the disease, except skin cancer. The interviewers were physiotherapists and physical educators previously trained to apply the questionnaire and to perform functional physical tests.

The dependent variables of this study were based on the self-reports of falls in the last twelve months, a fall (any fall event) and a recurrent fall (two or more fall events). A fall was considered "an unexpected event in which the subject finds themselves on the ground or at a lower level than before" ${ }^{\prime 1}$. For the characterization of the fall, the elderly were asked about their most recent fall, location, mechanism, circumstances, lighting at the time of fall, activity at the time of fall, time of day, consequences, need for rest, need to seek medical attention. The circumstance of a fall event was understood as the way in which the elderly fell (e.g. stumbling, slipping, losing balance). The mechanism of the fall is related to the displacement of the center of mass of the body (e.g. forward, sideways, backward).

The sociodemographic variables used were: gender and age group (65 to 79 years and 80 years and over). The subjective evaluation of health of the elderly was their personal and subjective impression of their own health and how they cared for health. The question asked was in general, you would say that your health is followed by the following "very good", "good", "fair", "poor" and "very poor".

The presence of depressive symptoms was evaluated through the application of the Geriatric Depression Scale (GDS), (fifteen-item version), translated and validated into the Portuguese language $e^{15}$. The participants were classified according to number of depressive symptoms: those with $\geq 5$ symptoms were considered positive for depression and those with $<5$ symptoms were considered without depression. The number of medications was identified by asking the elderly persons about the number of drugs that they had used regularly in the last three months. The number of diseases was evaluated through dichotomic responses and categorized as zero to one disease, two to three diseases and four or more diseases, based on the presence of diabetes, osteoporosis, arthritis/ rheumatism and urinary incontinence. The presence of the complaint of dizziness was identified through self-reporting in the last twelve months. Any feeling of spinning, turning, feeling light or heavy-headed, dizziness, wooziness or floating was considered dizziness.

The advanced activities of daily living ${ }^{16}$ include voluntary social, occupational and recreational activities, and total 12 activities. The activities that the elderly failed to perform or never performed were added together and the median was used to classify each individual (below the median: 0 to 5 activities impaired and above the median $>5$ 
activities impaired). Instrumental activities of daily living ${ }^{17}$ involve practical tasks of daily life, identified through a questionnaire containing self-reported answers about the need for some help, total help or independence. Activities in which the elderly require partial or total help were added together and the median was calculated. Elderly with $>1$ impaired activity were categorized as above the median and elderly persons with 0 impaired activities as below the median.

A descriptive analysis was performed and contingency tables were generated to evaluate the association between falling once and falling twice or more and the variables of interest, and to evaluate the association between the circumstances of the falls and the variables of interest. We used Fischer's exact test for the 2x2 tables and the Pearson chi-squared test to verify if there was an association between the variables. The significance level adopted was $\alpha<0.05$.

The Free and Informed Consent Form signed by all the research participants was approved by the Ethics Research Committee of PUC-SP, under research protocol $N^{\circ}$ 269/2007 for the FIBRA study in Barueri, and by the Ethics Research Committee of HCRP and FMRP-USP, under N ${ }^{\circ}$ 5018/2007.

\section{RESULTS}

Of the 774 elderly persons included in the study, 299 elderly persons $(38.6 \%)$ reported a fall in the last year. Of these 176 (58.9\%) fell once and 123 (41.1\%) reported having fallen twice or more. The mean age of fallers was $72.53 \pm 6.12$ years and $214(71.6 \%)$ were female. Table 1 shows the characteristics of the elderly in relation to the number of falls, comparing the elderly who suffered a fall in the last year with the elderly who fell on a recurring basis (two or more falls). Among the elderly aged 80 and over, two or more falls were significantly more prevalent than one fall. There was a significant increase in comorbidities (four or more diseases) in elderly patients who suffered recurring falls, with an increase in the proportion of elderly people who reported having arthritis or rheumatism, osteoporosis, urinary incontinence, dizziness and depression. In addition, the elderly persons who fell recurrently presented more limitations in instrumental and advanced activities of daily living.

Around 107 (35.8\%) of the elderly reported falling forward, 79 (26.4\%) sideways and $42(14 \%)$ backwards. Regarding the circumstances, 79 (26.4\%) reported having stumbled, 42 (14\%) slipped and 107 $(35.8 \%)$ lost their balance. There was an association between the number of falls and the mechanism and circumstance of the fall. Elderly patients who fell recurrently reported falling sideways, forwards or into a sitting position more often. In terms of circumstances, these same elderly persons reported having stumbled or lost their balance. Interestingly, the elderly who fell once described slipping as the most frequent circumstance. About $45 \%$ of the elderly who fell twice or more reported having reduced their activities due to the falls (Table 2).

There was no association between the fall mechanism and the variables of interest. There was an association between the number of medications and the circumstances of falls losing balance and slipping (Table 3). 
Table 1. Characterization of elderly persons with a history of one or two or more falls in relation to sociodemographic, physical and mental health and functionality variables among elderly persons living in the community (FIBRA Network; n=299). Baureri, São Paulo and Cuiabá, Mato Grosso, 2009-2010.

\begin{tabular}{|c|c|c|c|}
\hline Variables & $\begin{array}{l}\text { Fell once }(\mathrm{n}=176) \\
\mathrm{n}(\%)\end{array}$ & $\begin{array}{l}\text { Fell twice or more } \\
(\mathrm{n}=123) \mathrm{n}(\%)\end{array}$ & $p$-value \\
\hline $\begin{array}{l}\text { Female } \\
\text { Male }\end{array}$ & $\begin{array}{r}116(65.9) \\
60(34.1)\end{array}$ & $\begin{array}{l}98(79.7) \\
25(20.3)\end{array}$ & $<0.001$ \\
\hline $\begin{array}{l}\text { Age Range (years) } \\
65 \text { to } 79 \\
80 \text { or over }\end{array}$ & $\begin{array}{l}155(88.1) \\
21(11.9)\end{array}$ & $\begin{array}{l}98(79.7) \\
25(20.3)\end{array}$ & 0.04 \\
\hline $\begin{array}{l}\text { Perceived Health } \\
\text { Good or Very Good } \\
\text { Fair } \\
\text { Poor or Very Poor }\end{array}$ & $\begin{array}{l}91(51.7) \\
70(41.5) \\
12(6.8)\end{array}$ & $\begin{array}{l}52(42.3) \\
52(42.3) \\
19(15.4)\end{array}$ & 0.03 \\
\hline $\begin{array}{l}\text { Number of Illnesses } \\
0 \text { to } 1 \\
2 \text { to } 3 \\
4 \text { or more }\end{array}$ & $\begin{array}{l}58(33.3) \\
82(47.1) \\
34(19.5)\end{array}$ & $\begin{array}{l}26(21.1) \\
50(40.7) \\
17(38.2)\end{array}$ & $<0.001$ \\
\hline $\begin{array}{l}\text { Diabetes } \\
\text { Yes }\end{array}$ & $132(25.0)$ & $30(24.4)$ & 0.50 \\
\hline $\begin{array}{l}\text { Arthritis or Rheumatism } \\
\text { Yes }\end{array}$ & $59(33.5)$ & $66(46.3)$ & 0.02 \\
\hline $\begin{array}{l}\text { Osteoporosis } \\
\text { Yes }\end{array}$ & $123(30.1)$ & $60(44.7)$ & 0.01 \\
\hline $\begin{array}{l}\text { Urinary Incontinence } \\
\text { Yes }\end{array}$ & $32(18.3)$ & $83(32.5)$ & $<0.001$ \\
\hline $\begin{array}{l}\text { Number of Medications } \\
0 \text { to } 1 \\
2 \text { to } 3 \\
4 \text { or more }\end{array}$ & $\begin{array}{l}58(33.0) \\
68(38.6) \\
50(28.4)\end{array}$ & $\begin{array}{l}35(28.5) \\
46(37.4) \\
42(34.1)\end{array}$ & 0.52 \\
\hline $\begin{array}{l}\text { Dizziness in last year } \\
\text { Yes } \\
\text { No }\end{array}$ & $\begin{array}{l}79(44.9) \\
97(55.1)\end{array}$ & $\begin{array}{l}7863.4 \\
4536.6\end{array}$ & $<0.001$ \\
\hline $\begin{array}{l}\text { GDS } \\
\text { No depression } \\
\text { Depression }\end{array}$ & $\begin{array}{c}126(71.6) \\
50(28.4)\end{array}$ & $\begin{array}{l}70(56.9) \\
53(43.1)\end{array}$ & $<0.001$ \\
\hline $\begin{array}{l}\text { AADL by median } \\
\text { Below median }(0-5) \\
\text { Above median }(>5)\end{array}$ & $\begin{array}{l}86(49.1) \\
89(50.9)\end{array}$ & $\begin{array}{l}59(48.0) \\
64(52.0)\end{array}$ & 0.08 \\
\hline $\begin{array}{l}\text { IADL by median } \\
\text { Below median }(0) \\
\text { Above median }(>1)\end{array}$ & $\begin{array}{l}106(60.2) \\
70(39.8)\end{array}$ & $\begin{array}{l}59(48.0) \\
64(52.0)\end{array}$ & 0.03 \\
\hline
\end{tabular}

GDS: Geriatric Depression Scale; AADL: Advanced Activities of Daily Living; IADL: Instrumental Activities of Daily Living; Fisher's exact test or Pearson's chi-squared test for the value of $p$. 
Table 2. Characterization of most recent fall in relation to place, mechanism, lighting, time of day, consequences and circumstances of fall among elderly living in the community (Network FIBRA; n=299). Barueri, São Paulo and Cuiabá, Mato Grosso, 2009- 2010.

\begin{tabular}{|c|c|c|c|}
\hline Variables & $\begin{array}{l}\text { Fell once } \\
(\mathrm{n}=176) \mathrm{n}(\%)\end{array}$ & $\begin{array}{l}\text { Fell twice or more } \\
(\mathrm{n}=123) \mathrm{n}(\%)\end{array}$ & $p$ value \\
\hline $\begin{array}{l}\text { In relation to most recent fall } \\
\text { At home (outside) } \\
\text { At home (inside) } \\
\text { Away from home (known place) } \\
\text { Away from home (unknown place) }\end{array}$ & $\begin{array}{l}61(34.9) \\
46(26.3) \\
62(35.4) \\
6(3.4)\end{array}$ & $\begin{array}{l}45(36.9) \\
35(28.7) \\
37(30.3) \\
5(4.1)\end{array}$ & 0.82 \\
\hline $\begin{array}{l}\text { Mechanism of Fall } \\
\text { Fell sideways } \\
\text { Fell backwards } \\
\text { Fell forwards } \\
\text { Fell onto knees } \\
\text { Fell into sitting position }\end{array}$ & $\begin{array}{l}44(25.1) \\
32(18.3) \\
56(32.0) \\
28(16.0) \\
15(8.6)\end{array}$ & $\begin{array}{l}35(28.7) \\
10(8.2) \\
51(41.8) \\
12(9.8) \\
14(11.5)\end{array}$ & 0.03 \\
\hline $\begin{array}{l}\text { Lighting at time of fall } \\
\text { Well lit } \\
\text { Poorly lit }\end{array}$ & $\begin{array}{l}162(92.6) \\
13(7.4)\end{array}$ & $\begin{array}{c}108(89.3) \\
13(10.7)\end{array}$ & 0.32 \\
\hline $\begin{array}{l}\text { What time of day did the fall occur } \\
\text { Morning (6-12h) } \\
\text { Afternoon (12-18h) } \\
\text { Night (18-6h) }\end{array}$ & $\begin{array}{l}98(56.0) \\
50(28.6) \\
27(15.4)\end{array}$ & $\begin{array}{l}58(47.9) \\
37(30.6) \\
26(21.5)\end{array}$ & 0.29 \\
\hline $\begin{array}{l}\text { Rest required after fall } \\
\text { Yes } \\
\text { No }\end{array}$ & $\begin{array}{c}38(21.8) \\
136(78.2)\end{array}$ & $\begin{array}{l}29(23.8) \\
93(76.2)\end{array}$ & 0.69 \\
\hline $\begin{array}{l}\text { Required emergency care after fall } \\
\text { Hospitalization } \\
\text { Visit to doctor } \\
\text { None required }\end{array}$ & $\begin{array}{l}51(29.3) \\
7(4.0) \\
15(8.6) \\
51(58.0)\end{array}$ & $\begin{array}{l}32(26.2) \\
2(1.6) \\
10(8.2) \\
78(63.9)\end{array}$ & 0.57 \\
\hline $\begin{array}{l}\text { Reduced activity after fall } \\
\text { Yes, social activities } \\
\text { Yes, activities at home } \\
\text { No }\end{array}$ & $\begin{array}{c}15(8.6) \\
35(20.1) \\
124(71.3)\end{array}$ & $\begin{array}{l}14(11.5) \\
41(33.6) \\
67(54.9)\end{array}$ & 0.01 \\
\hline $\begin{array}{l}\text { Circumstances of fall } \\
\text { Stumbled } \\
\text { Slipped } \\
\text { Lost balance } \\
\text { Other }\end{array}$ & $\begin{array}{l}44(25.1) \\
32(18.3) \\
56(32.0) \\
43(24.6)\end{array}$ & $\begin{array}{l}35(28.5) \\
10(8.1) \\
52(42.3) \\
26(21.1)\end{array}$ & 0.04 \\
\hline
\end{tabular}




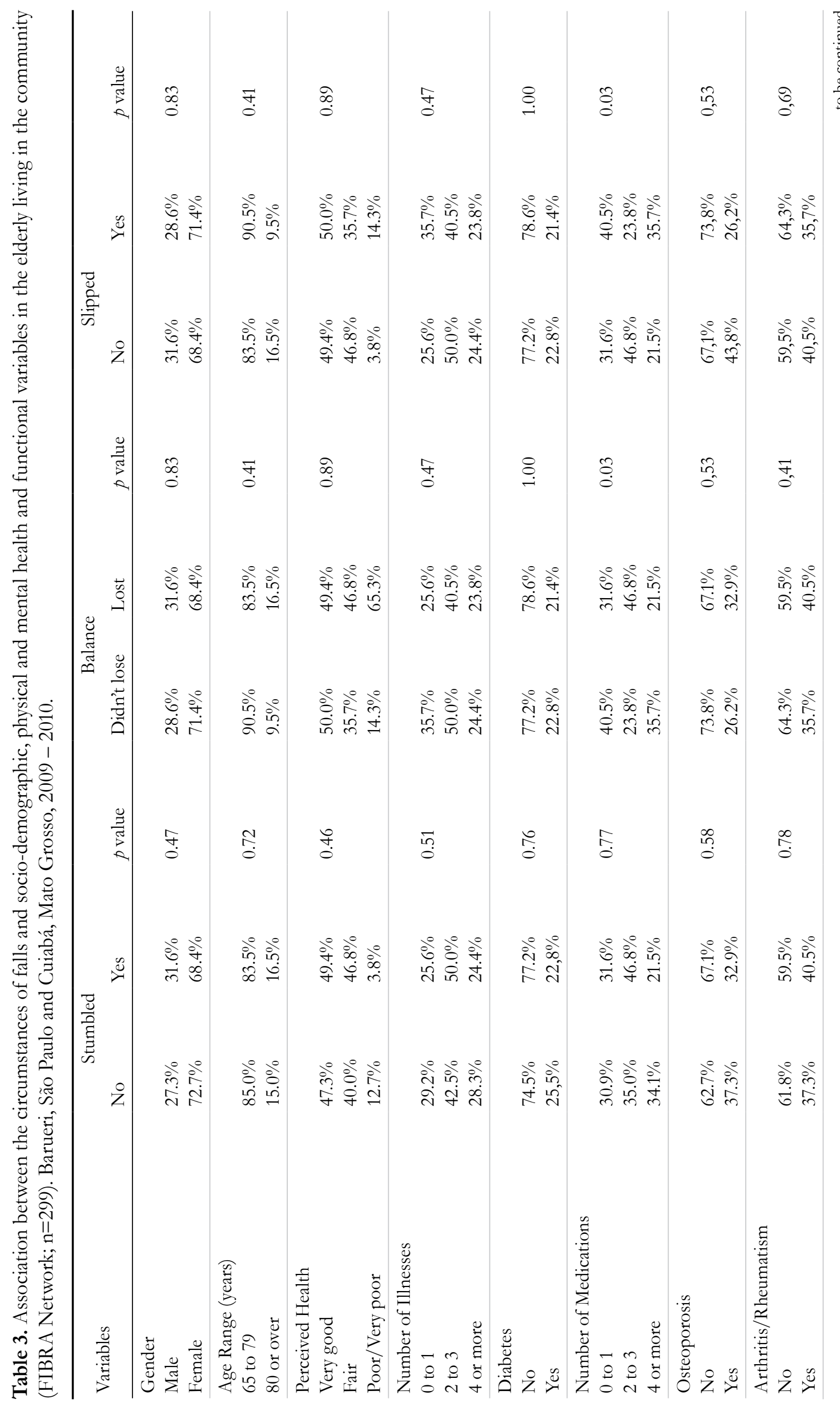




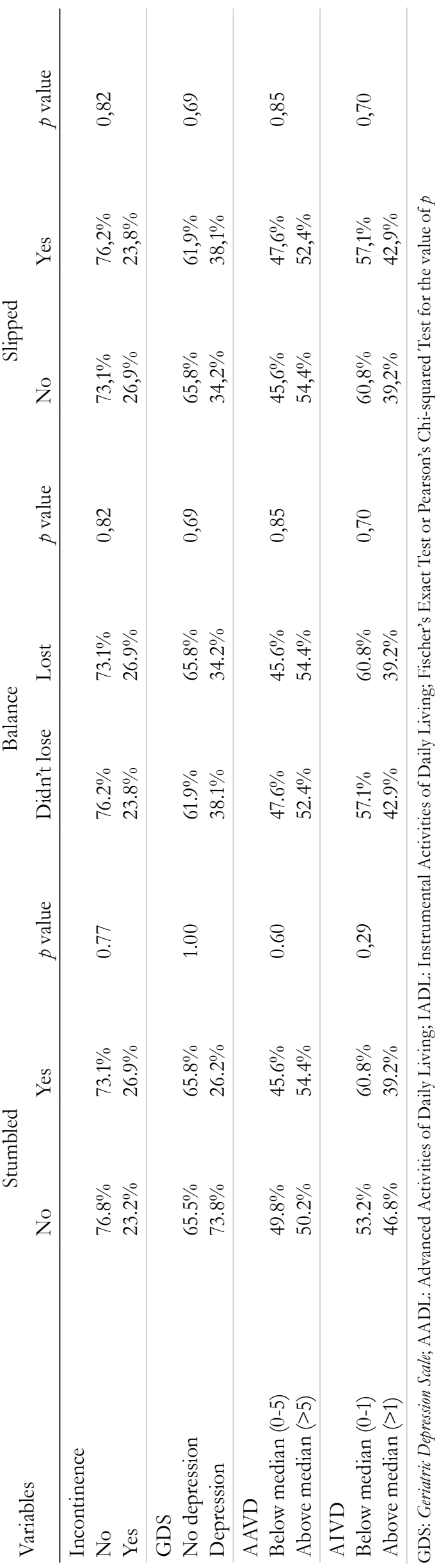




\section{DISCUSSION}

The results of the present study show that elderly persons who suffered recurring falls were women, aged between 65 and 79 years old, with more comorbidities, especially those that are risk factors for falls, and who presented greater impairment in functional performance and social participation. The characteristics of the most recent fall revealed that recurrent elderly fallers fell sideways, forward or into a sitting position more often, and the related circumstances were stumbling and losing balance, which differed from the elderly who fell once. However, there was no association between the mechanism of the fall and the variables studied, and only the number of medications was associated with the circumstance of losing balance and slipping.

The prevalence of falls among women was 79.7\%, a finding consistent with the results of Brazilian and non-Brazilian literature which show that women are more affected than males. This can occur due to greater physical frailty and a lower amount of lean mass and muscular strength in relation to men $^{18}$. The occurrence of falls is greater in elderly persons aged 80 years and over than in those aged 65 to 79 years. This result is attributed to the natural process of aging, which involves progressive losses of balance and muscle and bone mass ${ }^{19}$. Research has revealed that the regular practice of physical activity can minimize the deficits in balance and muscle mass associated with this process, helping to improve functional capacity, balance and strength ${ }^{20}$. Among the diseases studied, there was an association with arthritis/ rheumatism, urinary incontinence, osteoporosis, depression and dizziness. This finding was similar to that of a population-based study of 1,520 elderly people in Brazil ${ }^{21}$. Joint diseases and osteoporosis contribute to the reduction of physical capacity in the elderly, as well as causing inflammation and pain, and consequently influence balance and postural control, thus increasing the risk of falls. Dizziness was associated with falls. De Moraes et al. ${ }^{22}$ analyzed the factors associated with complaints of dizziness and found that $51.4 \%$ of elderly persons who complained of dizziness fell and $64.1 \%$ fell recurrently. In order to avoid falls, stability control mechanisms and postural orientation must function properly. Dizziness impairs this control and may make these elderly persons more susceptible to falls. Depression was also found to be associated with falls in this study, a finding also observed in other works ${ }^{5,21}$. A study carried out in Sweden found that stressful events and mobilizers of negative feelings acted as triggers for falls among the elderly ${ }^{23}$. In terms of perception of health, the present study found that most of the elderly reported having a good to very good perception of their own health. Elderly people with a positive perception of health and who have a history of falls may attribute falls to environmental factors ${ }^{24}$. It is possible that this population, who have preserved their functional capacity, expose themselves to greater risk, while frail elderly persons are able to cope only in environments with low physical demand $\mathrm{s}^{25}$. Most of the elderly investigated limited their social activities and instrumental activities of daily living. When the elderly fall, there is a tendency to reduce daily activities, either for fear of being exposed to the risk of falling or due to the protective attitudes of family members and caregivers ${ }^{10}$. This reduction can cause immobility and consequent muscular atrophy, facilitating the recidivism of falls.

Regarding the circumstances of falls, the main factors that contributed to recurring falls were stumbling and losing balance. Most falls are due to the loss of dynamic balance, or in other words, they occur during locomotion, being caused mainly by stumbling and slipping when walking ${ }^{26}$. Studies indicate that aging is associated with changes in gait patterns and balance, meaning that gait dysfunctions are the most common problem in the elderly population and their prevalence increases with age $^{26}$. Regarding the mechanisms of the falls, results showed that there was a higher frequency of elderly people who fell sideways and forward. The dynamics of gait are related to the sensorial integration of the vestibular, visual and proprioceptive systems, as well as muscular strength, joint mobility and adequate neuromotor control. Gait is a complex motor skill in which the body moves via a cyclic pattern of coordinated movements of the lower limbs ${ }^{3}$.

Greater muscle strength may provide more stable support during walking, and previous studies have shown that reduced muscle strength plays an important role in falls in the elderly $y^{27,28}$. In addition, exercises that improve muscle strength help reduce fear of falls and can have positive results in reducing falls in the future ${ }^{29}$. 
The present study indicates that the use of medications was related to the circumstances of the fall. Chronic medications may potentiate the risk of falls and cause effects such as orthostatic hypotension, cognitive dysfunction, balance disorders, dizziness, vertigo, drowsiness, motor dysfunction, reflex impairments, visual changes ${ }^{30}$. Therefore, the use of multiple medications among the elderly is associated with a negative outcome. In the studied population the use of two to three medications was associated with a loss of balance, which may be related to elderly persons who reported being dizzy and was statistically significant, corroborating the results of De Moraes et al. ${ }^{22}$. Slipping and the use of four or more medications were also associated, which can be explained by the impairment of reflexes that occurs due to the adverse effect of medications. These reflexes are diminished by the natural process of aging, especially that of protection ${ }^{31}$, and potentialized by the use of medication, thus impairing the corporal mobility leading the elderly to fall by slipping. Berg et al. ${ }^{26}$ reported that slipping was highly prevalent, accounting for $59 \%$ of falls in the elderly population. However, this study was not related to drugs.

The American Geriatrics Society and the British Geriatrics Society ${ }^{12}$ recommend that geriatricians ask elderly persons about their history of falls, allowing the doctor or gerontology professional to identify the possible contributing factors of falls. The period prior to the fall event and the post fall result should also be explored, enquiring if there was a loss of consciousness, if the individual stumbled, felt dizzy, or had difficulty getting up. Health professionals should ask about health conditions, and investigate the use of medications to see if there have been recent changes in the use of vasodilators, diuretics and hypnotic sedatives. Finally, it is important to ask about sight and the use of alcohol, if all possible causes are to be understood.

The present study has some limitations. It is a cross-sectional study, which does not allow the determination of risk factors for falls. There is possible memory bias as falls in the last 12 months were reported. Regarding medication, the reason for administration was not described, which impedes the identification of the action of the drug in relation to falls in the elderly population. Only the most recent fall was investigated, preventing typology from being determined. These limitations may explain why some of the associations were not found, and means the results should be used with caution.

\section{CONCLUSION}

The characteristics of falls were different for elderly persons who fell once and those who fell twice or more, which may guide health professionals, the elderly and their families in relation to specific strategies for the prevention of falls.

\section{ACKNOWLEDGEMENTS}

The authors would like to thank all the elderly persons who took part in the study and those who, directly or indirectly, contributed to this work.

\section{REFERENCES}

1. Marengoni A, Angleman S, Melis R, Mangialasche F, Karp A, Garmen A, et al. Aging with multimorbidity: a systematic review of the literature. Ageing Res Rev. 2011;10(4):430-9.

2. Burns ER, Stevens JA, Lee R. The direct costs of fatal and non-fatal falls among older adults - United States. J Safety Res. 2016;58:99-103.

3. Fasano A, Plotnik M, Bove F, Berardelli A. The neurobiology of falls. Neurol Sci. 2012;33(6):1215-23.
4. Tinetti ME, Kumar C. The patient who falls: "It's always a trade-off". JAMA. 2010;303(3):258-66.

5. Soares WJS, Moraes SA, Ferriolli E, Perracini MR. Fatores associados a quedas e quedas recorrentes em idosos: estudo de base populacional. Rev Bras Geriatr Gerontol. 2014;17(1):49-60.

6. Da Cruz DT, Ribeiro LC, Vieira MT, Teixeira MTB, Bastos RR, Leite ICG. Prevalência de quedas e fatores associados em idosos. Rev Saúde Pública. 2012;46:138-46. 
7. Portal Brasil. Quedas [Internet]. Brasília, DF: Ministério da Saúde; 2014 [acesso em 28 fev. 2017]. Disponível em: http://www.brasil.gov.br/saude/2012/04/quedas.

8. Ambrose AF, Paul G, Hausdorff JM. Risk factors for falls among older adults: a review of the literature. Maturitas. 2013;75(1):51-61.

9. Hill AM, Hoffmann T, Haines TP. Circumstances of falls and falls-related injuries in a cohort of older patients following hospital discharge. Clin Interv Aging. 2013;8:765-74.

10. Antes DL, D’Orsi E, Benedetti TRB. Circunstâncias e consequências das quedas em idosos de Florianópolis. Epi Floripa Idoso 2009*. Rev Bras Epidemiol. 2013;16(2):469-81.

11. Ferretti F, Lunardi D, Bruschi L. Causas e consequências de quedas de idosos em domicílio. Fisioter Mov. 2013;26(4):753-62.

12. American Geriatrics Society, British Geriatrics Society, American Academy of Orthopaedic Surgeons Panel on Falls Prevention. Guideline for the prevention of falls in older persons. J Am Geriatr Soc. 2001;49(5):664-72.

13. Brucki SM, Nitrini R, Caramelli P, Bertolucci PH, Okamoto IH. Sugestões para o uso do mini-exame do estado mental no Brasil. Arq Neuropsiquiatr. 2003;61(3B):777-81.

14. Lamb SE, Jorstad-Stein EC, Hauer K, Becker C; Prevention of Falls Network E; Outcomes Consensus G. Development of a common outcome data set for fall injury prevention trials: the Prevention of Falls Network Europe consensus. J Am Geriatr Soc. 2005;53(9):1618-22.

15. Paradela EMP, Lourenço RA, Veras RP. Validação da escala de depressão geriátrica em um ambulatório geral. Rev Saúde Pública. 2005;39:918-23.

16. Reuben DB, Laliberte L, Hiris J, Mor V. A hierarchical exercise scale to measure function at the Advanced Activities of Daily Living (AADL) level. J Am Geriatr Soc. 1990;38(8):855-61.

17. Lawton MP, Brody EM. Assessment of older people: self-maintaining and instrumental activities of daily living. Gerontologist. 1969;9(3):179-86.

18. Perracini MR, Ramos LR. Fatores associados a quedas em uma coorte de idosos residentes na comunidade. Rev Saúde Pública. 2002;36:709-16.

19. Siqueira FV, Facchini LA, Piccini RX, Tomasi E, Thumé E, Silveira DS, et al. Prevalência de quedas em idosos e fatores associados. Rev Saúde Pública. 2007;41:749-56.
20. Guimarães L, Galdino D, Martins F, Vitorino D, Pereira K, Carvalho E. Comparação da propensão de quedas entre idosos que praticam atividade física e idosos sedentários. Rev Neurociênc. 2004;12(2):68-72.

21. Rodrigues IG, Fraga GP, Barros MBA. Falls among the elderly: risk factors in a population-based study. Rev Bras Epidemiol. 2014;17:705-18.

22. De Moraes SA, Soares WJ, Ferriolli E, Perracini MR. Prevalence and correlates of dizziness in communitydwelling older people: a cross sectional population based study. BMC Geriatr. 2013;13:4.

23. Moller J, Hallqvist J, Laflamme L, Mattsson F, Ponzer S, Sadigh S, et al. Emotional stress as a trigger of falls leading to hip or pelvic fracture. Results from the ToFa study - a case-crossover study among elderly people in Stockholm, Sweden. BMC Geriatr. 2009;9:7.

24. Nyman SR, Ballinger C, Phillips JE, Newton R. Characteristics of outdoor falls among older people: a qualitative study. BMC Geriatr. 2013;13:125.

25. Oliveira AS, Trevizan PF, Bestetti MLT, Melo RC. Fatores ambientais e risco de quedas em idosos: revisão sistemática. Rev Bras Geriatr Gerontol. 2014;17(3):637-45.

26. Berg WP, Alessio HM, Mills EM, Tong C. Circumstances and consequences of falls in independent community-dwelling older adults. Age Ageing. 1997;26(4):261-8.

27. Granacher U, Gollhofer A, Hortobágyi T, Kressig RW, Muehlbauer T. The importance of trunk muscle strength for balance, functional performance, and fall prevention in seniors: a systematic review. Sports med. 2013;43(7):627-41.

28. Cheng YY, Wei SH, Chen PY, Tsai MW, Cheng IC, Liu $\mathrm{DH}$, et al. Can sit-to-stand lower limb muscle power predict fall status? Gait Posture. 2014;40(3):403-7.

29. Oh DH, Park JE, Lee ES, Oh SW, Cho SI, Jang $\mathrm{SN}$, et al. Intensive exercise reduces the fear of additional falls in elderly people: findings from the Korea falls prevention study. Korean J Intern med. 2012;27(4):417-25.

30. Dyks DSC. Interventions to Reduce MedicationRelated Falls. CME J. 2015;5(1):23-31.

31. Cunha P, Pinheiro LC. O papel do exercício físico na prevenção das quedas nos idosos: uma revisão baseada na evidência. Rev Port Med Geral Fam. 2016;32:96-100. 